\title{
The Metabolism of Polyphosphates in Chlorobium thiosulfatophilum
}

\author{
By J. A. COLE AND D. E. HUGHES \\ Medical Research Council Unit for Research in Cell Metabolism, \\ Department of Biochemistry, University of Oxford
}

(Received 29 July 1964)

\begin{abstract}
SUMMARY
The synthesis and breakdown of long chain polyphosphate in Chlorobium thiosulfatophilum was studied. An enzyme is present which reversibly transfers phosphate groups from polyphosphate to adenosine diphosphate to give adenosine triphosphate. A second enzyme, an adenosine triphosphatase probably located in the cytoplasmic membrane, hydrolyses the adenosine triphosphate so formed to adenosine diphosphate and orthophosphate.
\end{abstract}

\section{INTRODUCTION}

Hughes, Conti \& Fuller (1963) characterized long chain 'acid-insoluble' polyphosphate from the green sulphur bacterium Chlorobium thiosulfatophilum, and showed that this was associated with granules which were electron dense in thin sections in the electron microscope and stained metachromatically when treated with basic dyes such as toluidine blue. Experiments designed to measure photophosphorylation in cell-free extracts demonstrated a release of orthophosphate (P) which was stimulated by adenosine diphosphate (ADP), but was absent from cells depleted of polyphosphate. It was suggested that polyphosphate in Chlorobium is degraded in the presence of ADP to give adenosine triphosphate (ATP), and that this is hydrolysed by an adenosine triphosphatase (ATPase) to release orthophosphate and regenerate ADP according to the following scheme:

$$
\begin{gathered}
(\text { Polyphosphate })_{n}+\mathrm{ADP} \rightleftharpoons(\text { Polyphosphate })_{n-1}+\text { ATP } \\
\text { ATP } \rightarrow \text { ADP }+ \text { orthophosphate }
\end{gathered}
$$

In the present paper, it is shown that the orthophosphate does arise from polyphosphate breakdown under the control of ADP; ATP is formed as an intermediate and can be utilized for other energy-consuming processes such as the phosphorylation of glucose.

\section{METHODS}

Growth of organism. The growth medium used for the strict anaerobe Chlorobium thiosulfatophilum, strain 8346, was that described by Larsen (1953). The mixed medium was poured into sterile Pyrex reagent bottles (1, 2, 5 l. with ground-glass stoppers), inoculated, and the bottles then filled completely to avoid trapping air bubbles with the stopper. The freshly inoculated bottles were stored overnight in 
complete darkness to remove any traces of oxygen by interaction with the hydrogen sulphide in the medium. They were then transferred to the photosynthesis room, which was illuminated with and maintained at $30^{\circ}$ by a thermostatically controlled bank of $100 \mathrm{~W}$. tungsten lamps. The inoculum consisted of organisms grown for 3-5 days and its volume was $20-30 \%(v / v)$ of the medium into which it was inoculated, this high volume being necessary to achieve satisfactory growth of dark-green to yellow-green organisms. Elementary sulphur was deposited in variable amounts in the medium during growth; very high light intensities appeared to increase the deposition of sulphur and led to low yields of organisms yellow in colour instead of green.

Preparation of cell-free extracts. Cultures were harvested after 3-6 days, depending on the rate of growth, by centrifugation at $14,000 \mathrm{~g}$ in $250 \mathrm{ml}$. containers (MSE Speed 17 centrifuge). Organisms were washed by suspending them in $0 \cdot 1 \mathrm{M}$-tris + maleate buffer ( $\mathrm{pH} 7 \cdot 0$ ) and centrifuging again at 14,000 $\mathrm{g}$. Organisms together with fine particles of sulphur collected from the medium were crushed in a Hughes (1951) bacterial press at $-\mathbf{2 5}^{\circ}$. The disintegrated organisms were collected and resuspended in $0.1 \mathrm{M}$-tris + maleate buffer $(\mathrm{pH} 7 \cdot 0)$ at $0^{\circ}$ by using a Kontés type glass homogenizer. Next, $\mathbf{0} \cdot 1 \mathrm{mg}$. deoxyribonuclease (DNAase) in distilled water was added for each $5.0 \mathrm{ml}$. of cell extract, and the preparation left at $0^{\circ}$ for $30 \mathrm{~min}$. Digestion of the deoxyribonucleic acid (DNA) was indicated by a marked decrease in the viscosity which facilitated further fractionation by differential centrifugation.

Electron microscopy. Whole organisms or fractions obtained by centrifugation were mounted by the 'blot dry' method on formvar-coated grids, the preparations being unfixed or fixed in $1 \%$ osmic acid. A mixture of $10 \% \mathrm{Pd}$ and $90 \% \mathrm{Au}$ was used for shadowing. Grids were examined in the Akashi TSR 50 Tronoscope at magnifications from $\times 500$ to $\times 17,000$.

Extraction of polyphosphate. Polyphosphate was extracted from organisms in two fractions as described by Muhammed (1959). First the organisms were shaken with $5 \%$ trichloroacetic or perchloric acid at $0^{\circ}$. This procedure was repeated, the flask being shaken for $1 \mathrm{hr}$ each time. The residue was collected by centrifugation, and the extract contained 'acid-soluble' low molecular weight polyphosphate. The residue was then washed with distilled water and extracted with $10 \%$ trichloroacetic or perchloric acid, previous work (Muhammed, 1959) having shown that all the remaining polyphosphate is extracted by $10 \mathrm{vol}$. of acid within $4 \mathrm{hr}$ at $20^{\circ}$. Both extracts were neutralized with alkali, brought to $\mathrm{pH} 3.5$ with $5 \mathrm{M}$-acetate buffer, and treated with saturated $\mathrm{BaCl}_{2}$ solution. Barium polyphosphate was allowed to separate out at $0^{\circ}$ overnight and then collected by centrifugation. The barium salt was washed twice with acetate buffer ( $\mathrm{pH} \mathrm{3.5)}$ and once with acetone, and the polyphosphate content estimated as orthophosphate liberated after hydrolysis with $\mathrm{N}-\mathrm{HCl}$ for $7 \mathrm{~min}$. at $100^{\circ}$.

Chemicals. Sodium polyphosphate was prepared by heating $\mathrm{KH}_{2} \mathrm{PO}_{4}$ at $780^{\circ}$ as described by Pfanstiel \& Iler (1952). When uniformly ${ }^{32}$ P-labelled material was prepared, up to $1 \mathrm{mc}$. of carrier-free orthophosphate was added.

Adenosine triphosphate (ATP) was labelled in the terminal position by the method of Glynn \& Chappel (1964). 1 mc. of ${ }^{32} \mathrm{P}$-orthophosphate yielded $0 \cdot 8 \mathrm{mc}$. of radioactive ATP, $98 \%$ of the ${ }^{32} \mathrm{P}$ being in the terminal position; small amounts of ADP were also present. 
All other chemicals were commercial specimens, and were used without further purification.

Chemical estimations. Inorganic orthophosphate was estimated by the method of Fiske \& SubbaRow (1925). Polyphosphate was estimated as orthophosphate after hydrolysis at $100^{\circ}$ for 7 min. Any orthophosphate present was determined before hydrolysis.

Chromatography. Nucleotides were isolated by the method of Krebs \& Hems (1953) in which orthophosphate is separated by ascending chromatography in the Hanes \& Isherwood (1949) solvent. The paper was dried, phosphate removed, and nucleotides resolved by descending chromatography in isobutyric acid + ammonia. Orthophosphate or nucleotide spots were located either by their ${ }^{32} \mathrm{P}$ activity by using an end-window counter, or colorimetrically by a modification of the method of Hanes \& Isherwood (1949) in which the nucleotides were hydrolysed by heating in an oven at $80^{\circ}$ after the ammonium molybdate spray; the blue colour was developed by illumination from an ultraviolet lamp for $10 \mathrm{~min}$.

Samples expected to contain ${ }^{32} \mathrm{P}$-labelled glucose-6-phosphate (G-6-32P) were chromatographed by the descending technique with the isobutyric acid + ammonia solvent described above to separate other phosphorus compounds from the sugar phosphates. The paper was dried, examined under the u.v. lamp and segments between the origin and the ATP spot cut off. These were eluted with water for $2 \mathrm{hr}$ to bring the bulk of the ${ }^{32} \mathrm{P}$ activity in this segment into solution. The eluate was then chromatographed by descending chromatography with solvent $80 \mathrm{vol}$. methanol +15 vol. $90 \%(\mathrm{w} / \mathrm{v})$ formic acid $+5 \mathrm{vol}$. of $0.002 \mathrm{M}-\mathrm{ED} T A$ as solvent (Bandurski \& Axelrod, 1951). After $6 \mathrm{hr}$ the chromatogram had run $30 \mathrm{~cm}$. and a separation of G-6-P from glucose-1-phosphate and other sugar phosphates was obtained. The paper was dried, and the position of the $\mathrm{G}-6-{ }^{32} \mathrm{P}$ determined by an end-window counter, and confirmed by comparing it with the position of unlabelled marker G-6-P after development of both by spraying with the Hanes \& Isherwood (1949) reagent described previously.

Measurement of ${ }^{32} \boldsymbol{P}$ radioactivity. The end-window counter used was the Panax Scaling Unit type D657 (Redhill, Surrey) the end-window counter operating at a voltage of $1625 \mathrm{~V}$.

Liquid ionization counting was done in a $10 \mathrm{ml}$. counting tube type M 6 (supplied by 20 th Century Electronics Ltd., Croydon, Surrey) operating at $1090 \mathrm{~V}$. in a lead castle from E.R.D. Engineering Co. Ltd. (Slough, Middlesex). The scaling unit with 'autocounts' and 'Autotime' refinements was type N 530 F obtained from Ecko Electronics Ltd. (Southend-on-Sea, Essex).

Estimation of enzymic activity. Cell extracts and other components to be incubated were put into $5 \mathrm{ml}$. Pyrex tubes standing in ice at $0^{\circ}$, made up to standard volume and mixed. Before and after incubation, 0.1-1.0 ml. samples were transferred to tubes containing the same volume of $1 \%(\mathrm{w} / \mathrm{v})$ solution, and allowed to stand at $0^{\circ}$ for several hours in the cold. Trichloroacetic acid $(0.5 \mathrm{ml} ., 10 \%, \mathrm{w} / \mathrm{v}$, TCA) was then added to precipitate protein and polyphosphate as a protein-polyphosphate complex and the tubes centrifuged at $6000 \mathrm{~g}$ for $\mathbf{2} \mathrm{min}$. Samples of the clear supernatant fluid were then immediately analysed for orthophosphate. Control experiments to study the efficiency of this procedure for removing polyphosphate showed that the method finally adopted was satisfactory. 


\section{RESULTS}

Phosphate content of whole organisms and extracts. Approximately 5 g. (wet wt.) organisms were collected by centrifugation, washed with $0.9 \%$ saline and extracted twice with $5 \%$ and once with $10 \%$ trichloroacetic acid. Acid-labile phosphate present in the $10 \%$ TCA extract was taken as the polyphosphate content of the organisms, and amounted to $40 \%$ of the cell total-phosphorus.

Cell-free extracts from such organisms were centrifuged at various speeds and the polyphosphate content of supernatant fluids and solid residues estimated (Table 1). Both supernatant fluids and solid residues contained polyphosphate in sufficient amounts to account for the orthophosphate formation studied in the subsequent sections. This widespread distribution of polyphosphate in fractions separated from disintegrated organisms is similar to that found by Muhammed (1959) and is probably due to the fragmentation of the metachromatic granules.

Table 1. Polyphosphate content of cell-free extracts of Chlorobium thiosulfatophilum prepared by centrifugation

Crude extract $(12.0 \mathrm{ml}$.) was centrifuged at $25,000 \mathrm{~g}$ for $30 \mathrm{~min}$.; then at $10,000 \mathrm{~g}$ for $1 \mathrm{hr}$ and then $20 \mathrm{hr}$. Polyphosphate was extracted and estimated in the solid residues and supernatant fluids as described in the text.

Fraction

$25,000 \mathrm{~g}$ extract $100,000 \mathrm{~g}(1 \mathrm{hr})$ extract $100,000 \mathrm{~g}(20 \mathrm{hr})$ extract
Supernatant fluids.

Polyphosphate content ( $\mu$ mole)

389

355

162
Residues.

Polyphosphate content ( $\mu$ mole)

193

Table 2. ADP dependence of orthophosphate release from crude cell-free extracts of Chlorobium thiosulfatophilum

Crude extract $(1.0 \mathrm{ml}$. containing $0 \cdot 1 \mathrm{~g}$ wet weight organism $/ 9 \mu$ mole synthetic polyphosphate) and ADP in a total vol. of $2.0 \mathrm{ml}$. were incubated at $27^{\circ}$ for $4 . \mathrm{hr}$. $0.5 \mathrm{ml}$. $1 \%(w / v)$ bovine serum albumin solution was used to precipitate polyphosphate. Samples were analysed for orthophosphate before and after incubation.

$\begin{array}{ccc} & \begin{array}{c}\text { ADP } \\ \text { added } \\ (\mu \text { mole })\end{array} & \begin{array}{c}\text { Orthophosphate } \\ \text { released } \\ (\mu \text { mole })\end{array} \\ \text { Expt. 1 } & 0 & 0 \cdot 4 \\ & \mathbf{3 \cdot 5} & 2 \cdot 7 \\ \text { Expt. 2 } & \mathbf{7 \cdot 0} & \mathbf{2 \cdot 9} \\ & 14 \cdot 0 & 0 \cdot 1 \\ & 0 & 3 \cdot 3 \\ & 1 \cdot 6 & 4 \cdot 9 \\ & 9 \cdot 5 & 6 \cdot 9 \\ & 38 \cdot 0 & 1 \cdot 6\end{array}$

Phosphate formation by cell-free extracts. The crude cell-free extract was incubated with and without added ADP. Low concentrations of ADP stimulated, but high concentrations inhibited the release of orthophosphate (Table 2). After centrifuging 
at $6000 \mathrm{~g}$ for $10 \mathrm{~min}$. to remove uncrushed organisms and larger pieces of cell debris, the supernatant fluid was incubated with $3 \cdot 2 \mu$ moles uniformly ${ }^{32}$ P-labelled synthetic polyphosphate, with and without ADP. Release of orthophosphate, measured either colorimetrically or by radioactivity, was higher in the presence of ADP (Table 3). The ratio of orthophosphate release with and without ADP (1.4) was approximately equal to the corresponding ratio of the increase in radioactivity $(1 \cdot 26)$. This agreement supports the idea that the bulk of the orthophosphate formed arose from polyphosphate and that added synthetic polyphosphate was metabolized at the same rate as the endogenous material.

Table 3. Metabolism of radioactive synthetic polyphosphate by crude extracts of Chlorobium thiosulfatophilum

The cell-free extract was incubated with $3 \cdot 2 \mu$ mole ${ }^{32} \mathrm{P}$-labelled synthetic polyphosphate, and with and without added ADP.

$\begin{array}{ccc}\begin{array}{c}\text { ADP } \\ \text { added } \\ (\mu \text { mole })\end{array} & \begin{array}{c}\text { Orthophosphate } \\ \text { released } \\ (\mu \text { mole })\end{array} & \begin{array}{c}\text { Increase in } \\ \text { radioactivity } \\ \text { after incubation } \\ (\text { counts } / 100 \text { sec. })\end{array} \\ 7 & 14 \cdot 0 & 592 \\ 0 & 9 \cdot 1 & 463\end{array}$

Table 4. Effect of centrifugation on orthophosphate release from Chlorobium extracts

$1.0 \mathrm{ml}$. samples of cell-free extracts obtained after different degrees of centrifugation (see text) were incubated at $27^{\circ}$ for $5 \mathrm{hr}$ with and without added ADP and polyphosphate. Both the increase in radioactivity in the orthophosphate fraction, and the orthophosphate released during the incubation period were assayed.

\begin{tabular}{|c|c|c|c|c|c|c|c|}
\hline $\begin{array}{c}25,000 \mathrm{~g} \\
\text { residue } \\
(\mathrm{ml} .)\end{array}$ & $\begin{array}{c}25,000 \mathrm{~g} \\
\text { supernatant } \\
\text { fluid } \\
\text { (ml.) }\end{array}$ & $\begin{array}{c}100,000 \mathrm{~g} \\
\text { residue } \\
\text { (ml.) }\end{array}$ & $\begin{array}{l}100,000 \mathrm{~g} \\
\text { supernatant } \\
\text { fluid } \\
\text { (ml.) }\end{array}$ & $\begin{array}{c}\text { ADP } \\
\text { added } \\
\text { mole }\end{array}$ & $\begin{array}{c}\text { Poly }{ }^{32} \mathbf{P} \\
\text { added } \\
\text { mole }\end{array}$ & $\begin{array}{c}\mathrm{P}_{i}^{*} \\
\text { released } \\
\text { mole }\end{array}$ & $\begin{array}{c}{ }^{32} \mathrm{P}_{\dagger} \\
\text { released } \\
\text { (counts } \\
100 \text { sec. }\end{array}$ \\
\hline 1.0 & - & - & - & - & $3 \cdot 5$ & $0 \cdot 1$ & 24 \\
\hline $1 \cdot 0$ & - & - & - & 7 & 3.5 & $0 \cdot 1$ & 44 \\
\hline- & $1 \cdot 0$ & - & - & - & $3 \cdot 5$ & $4 \cdot 8$ & 405 \\
\hline - & $1 \cdot 0$ & - & - & 7 & $3 \cdot 5$ & $9 \cdot 3$ & 591 \\
\hline- & - & $1 \cdot 0$ & - & - & $\mathbf{3 \cdot 5}$ & $0 \cdot 3$ & 36 \\
\hline- & - & $1 \cdot 0$ & - & 7 & $3 \cdot 5$ & 0.5 & 182 \\
\hline- & - & $1 \cdot 0$ & - & - & - & $0 \cdot 6$ & - \\
\hline - & - & $1 \cdot 0$ & - & 7 & - & 0.5 & - \\
\hline - & - & - & $1 \cdot 0$ & - & $3 \cdot 5$ & $4 \cdot 6$ & 472 \\
\hline- & - & - & $1 \cdot 0$ & 7 & 3.5 & $9 \cdot 0$ & 620 \\
\hline- & - & - & $1 \cdot 0$ & - & - & $5 \cdot 3$ & - \\
\hline - & - & - & $1 \cdot 0$ & 7 & 一 & $10 \cdot 8$ & - \\
\hline
\end{tabular}

* $\mathbf{P}_{i}+$ inorganic $\mathbf{P}$.

$\dagger$ These results give the increase in ${ }^{32} \mathrm{P}$ activity (counts/100 sec.) in the orthophosphate samples assayed. Polyphosphate had been removed as the protein complex with TCA.

Effect of centrifugation. The crude extract was centrifuged at $25,000 \mathrm{~g}$ for $30 \mathrm{~min}$. and separated into supernatant fluid and residue fractions. The supernatant fluid contained most of the dark green pigment and the particles measuring about $200 \AA$ in diameter which appeared to be similar to those previously found to photophosphorylate (Hughes et al. 1963). An attempt was made to isolate these particles 
free from contaminating cytoplasmic membrane by further centrifugation at $100,000 \mathrm{~g}$ for $1 \mathrm{hr}$ and then for $20 \mathrm{hr}$ at this relative centrifugal force (RCF). Electron micrographs showed that all fractions obtained contained small pieces of cell membrane, and that these tended to associate in clumps with other organelles and cell fragments. The stimulation of orthophosphate release was greater in the supernatant fluids of these centrifuged fractions. They also were found to yield labelled orthophosphate from added synthetic ${ }^{32} \mathrm{P}$-labelled polyphosphate (Table 4).

Some preliminary experiments were made in which a bacterial ATPase prepared from Lactobacillus arabinosus was added to the extracts. Stimulation of orthophosphate release from polyphosphate was found, but the experiments were unsatisfactory because the ATPase preparation was found to have polyphosphatase and a marked ADPase activity which gave rise to high blanks.

Table 5. Formation of ${ }^{32} \boldsymbol{P}$-orthophosphate from radioactive $\boldsymbol{A T P}$

\begin{tabular}{|c|c|c|}
\hline \multicolumn{3}{|c|}{$\begin{array}{l}\text { Supernatant fluids from centrifuged extracts of Chlorobium thiosulfatophilum were } \\
\text { incubated with }{ }^{32} \text { P-labelled ATP. Samples were chromatographed before and after } \\
\text { incubation to separate orthophosphate and nucleotide phosphates, and the release of } \\
{ }^{32} \text {-orthophosphate from ATP determined. }\end{array}$} \\
\hline$\mu$ mole $\mathbf{P}_{i}$ released & $\begin{array}{l}25,000 g \\
\text { supernatant } \\
\text { fluid } \\
\mathbf{9 \cdot 7}\end{array}$ & $\begin{array}{l}\mathbf{1 0 0 , 0 0 0 g} \\
\text { supernatant } \\
\text { fluid } \\
\mathbf{2 \cdot 9}\end{array}$ \\
\hline $\begin{array}{l}\text { Increase in }{ }^{32} \mathrm{P} \text {-activity in } \mathrm{P}_{i} / 10 \mathrm{l} \text {. incubation } \\
\text { mixture } / 400 \text { sec. }\end{array}$ & 1160 & 436 \\
\hline Corresponding decrease in ATP radioactivity & 920 & 404 \\
\hline
\end{tabular}

Most fractions formed ${ }^{32} \mathrm{P}$-orthophosphate from added $\mathrm{AT}^{32} \mathrm{P}$ (Table 5). The activity was greatest in the crude fractions and was decreased in the supernatant fluids of fractions centrifuged at highest speeds $(100,000 \mathrm{~g})$. This is consistent with the idea that the bulk of the bacterial ATPase activity is associated with particulate fractions which in some bacteria are derived wholly from the cytoplasmic membrane (Hughes, 1962). As stated above, it has not yet been found possible to prepare purified membrane fractions from Chlorobium.

The supernatant fluids were incubated with ATP $(5 \mu \mathrm{M})$ and ADP. Phosphate formation was decreased from $9 \cdot 7$ to $6.0 \mu$ mole for the $25,000 \mathrm{~g}$ supernatant fluid when extra ADP was present, and from $2 \cdot 9$ to $2 \cdot 0 \mu$ mole for the $100,000 \mathrm{~g}(1 \mathrm{hr})$ extract. This suggests that the ATPase is inhibited by ADP.

Formation of ATP from polyphosphate. The $25,000 \mathrm{~g}$ supernatant fluid extract was incubated with ${ }^{32} \mathrm{P}$-labelled polyphosphate and ADP, and samples were chromatographed to separate nucleotide phosphates and orthophosphates from polyphosphate. Spots corresponding in position to ATP, ADP, orthophosphate, were found to be labelled together with an unidentified spot. The ATP spot was the most active; the orthophosphate had about $60 \%$ of the ATP activity, and both the ADP and the unidentified spot approximately $25 \%$ of that of the ATP. These proportions suggest that $\mathrm{ADP}$ and the unidentified fraction arose from secondary reactions of orthophosphate and ATP. The unidentified spot had an $R_{F}$ value, relative to marker AMP, of $0 \cdot 4$, the value characteristic of sugar phosphates. These results are consistent with the presence of an enzyme similar to that in Escherichia coli 
(Kornberg, Kornberg \& Sims, 1956) which can form ATP from polyphosphate and ADP.

To establish further that polyphosphate gave rise to ATP directly, glucose and hexokinase were added to the usual incubation mixture. After incubation, $3 \%(\mathrm{v} / \mathrm{v})$ bovine serum albumin and $10 \%(\mathrm{w} / \mathrm{v})$ TCA were added to remove polyphosphate, cell debris and protein, and the supernatant fluid after centrifugation was chromatographed to separate G-6-P from nucleotide phosphates and other sugar phosphates. The sugar phosphate spot was eluted and concentrated by evaporation. Standard marker G-6-P was chromatographed alone and with the test sample, and in each case the standard and the radioactive spot had identical $R_{F}$ values. The ${ }^{32 P}$-activity found in G-6-P after incubation was $70 \%$ of the activity originally added as polyphosphate. In previous experiments with synthetic polyphosphate in which orthophosphate release was followed, about $10 \%$ of the added polymer only was metabolized.

The reversibility of the enzyme which catalysed the phosphorylation of ADP by polyphosphate was tested by incubating the $25,000 \mathrm{~g}$ supernatant fluid extract with ${ }^{32} \mathrm{P}$-labelled ATP, and isolating the polyphosphate formed. After $5 \mathrm{hr}$ at $31^{\circ}$, carrier Kurrol's salt, $5 \%(\mathrm{v} / \mathrm{v})$ albumin and $10 \%(\mathrm{w} / \mathrm{v})$ TCA were added to the incubation mixture. The resulting precipitate was collected by centrifugation, extracted with $10 \%(\mathrm{w} / \mathrm{v})$ TCA for $4 \mathrm{hr}$ and barium polyphosphate precipitated at $\mathrm{pH} \mathrm{3.5}$. This was washed with two volumes of water and two of ethanol to ensure complete removal of ATP. The precipitate was then spread on a filter paper, air dried, and the radioactivity counted with the end-window apparatus; $12.9 \%$ of the original activity added as $\mathbf{A T}^{\mathbf{3} 2} \mathbf{P}$ was found in this polyphosphate.

\section{DISCUSSION}

The presence of two enzymes, one reversibly forming ATP from polyphosphate in the presence of ADP, and the other hydrolysing ATP to ADP + orthophosphate, would account for these and all previous observations of ADP-stimulated phosphate release in cell-free extracts of Chlorobium thiosulfatophilum. The polyphosphate metabolic pathway may be summarized as:

$$
\begin{aligned}
(\text { Polyphosphate })_{n}+\mathrm{ADP} & \rightleftharpoons \mathrm{ATP}+(\text { polyphosphate })_{n-1} \\
\mathrm{ATP}+\mathrm{H}_{2} \mathrm{O} & \rightarrow \mathrm{ADP}+\mathrm{H}_{3} \mathrm{PO}_{4}
\end{aligned}
$$

The inhibition of orthophosphate release by high concentrations of ADP, the decrease in ATPase activity in the presence of added ADP, and the high rate of formation of G-6-P when excess glucose + hexokinase are present, all suggest that reaction (2) is the rate-limiting one and that polyphosphate breakdown is controlled by the concentration of ADP. The reversibility of enzyme (1) shows that it is similar to that found in Escherichia coli by Kornberg et al. (1956) and Kornberg (1957). Both enzymes reversibly transfer terminal ' high energy' phosphate units from polyphosphate to ADP to form ATP. It would appear that, in this phototrophic organism Chlorobium thiosulphatophilum, when ATP is formed in excess of other requirements by photophosphorylation (Arnon, 1959), polyphosphate is synthesized. Under conditions where ATP utilization is high, net breakdown of polyphosphate could occur. This would be similar to the mechanism proposed for chemohetero- 
trophs (Hughes \& Muhammed, 1962) where the disappearance of polyphosphate and metachromatic granules has been associated with rapid growth (Harold, 1963). Polyphosphate in this organism, by its ability to give rise to ATP, may be regarded as an 'energy store' or 'phosphagen'. No evidence has been found in the present work for transference of phosphate from polyphosphate to other acceptors directly without the intermediation of ATP (Szymona, 1962).

Thanks are due to Miss $\mathbf{H}$. Volman and Miss A. West for valuable technical assistance. This work was aided by grants to the Department from the Rockefeller Foundation, National Institutes of Health, Bethesda, Md., U.S.A., and the United States Air Force.

\section{REFERENCES}

Arnon, D. I. (1959). Conversion of light into chemical energy in photosynthesis. Nature, Lond. 184, 10.

Bandursky, R. S. \& Axelrod, B. (1951). The chromatographic identification of some biologically important phosphate esters. J. biol. Chem. 193, 405.

Fiske, O. H. \& SubbaRow, Y. (1925). The colorimetric determination of phosphorus. J. biol. Chem. 66, 375.

GlynN, I. M. \& Chappeli, J. B. (1964). A simple method for the preparation of ${ }^{32} \mathrm{P}$ labelled adenosine triphosphate of high specific activity. Biochem. J. 90, 147.

HaNes, C. S. \& Ishenwood, F. A. (1949). Separation of phosphoric esters on the filter paper chromatogram. Nature, Lond. 164, 1107.

Harold, F. M. (1963). Accumulation of inorganic polyphosphate in Aerobacter aerogenes. I. Relationship to growth and nucleic acid synthesis. J. Bact. 86, 216.

Hughes, D. E. (1951). A press for disrupting bacteria and other microorganisms. Brit. $J$. exp. Path. 32, 97.

Hughes, D. E. (1962). The bacterial cytoplasmic membrane. J. gen. Microbiol. 29, 39.

Hughes, D. E., ConTi, S. F. \& Fuller, R. C. (1963). Inorganic polyphosphate metabolism in Chlorobium thiosulphatophilum. J. Bact. 85, 577 .

Hughes, D. E. \& Muhammed, A. (1962). Acides ribonucléiques et polyphosphates. Colloques int. Cent. natn. Rech. scient. 106, 591.

Kornberg, A., Konnberg, S. R. \& Sims, E. S. (1956). Metaphosphate synthesis by an enzyme from Escherichia coli. Biochim. biophys. Acta, 20, 215.

KorNBErg, S. R. (1957). Adenosine triphosphate synthesis by an enzyme from Escherichia coli. Biochim. biophys. Acta, 26, 294.

Krebs, H. A. \& Hems, R. (1953). Some reactions of adenosine and inosine phosphates in animal tissues. Biochim. biophys. Acta, 12, 172.

LARSEN, H. (1953). Microbiology and biochemistry of the photosynthetic green sulphur bacteria. K. norske vidensk. Selsk. Skr. 1-205

Munammed, A. (1959). The metabolism of phosphate polymers in microorganisms. D.Phil. Thesis, Oxford University.

Pfanstiel, R. \& Iler, R. K. (1952). Potassium metaphosphate-molecular weight, viscosity behaviour and rate of hydrolysis of the non cross-linked polymer. J. Amer. chem. Soc. 74, 6059.

Szymona, M. (1962). Purification and properties of the new hexokinase utilising inorganic polyphosphate. Acta biochim. polonica, 9, 165. 